Sacrificing Soldiers on the National Mall 
The publisher gratefully acknowledges the generous support of the Abmanson Foundation Humanities Endowment Fund of the University of California Press Foundation. 


\title{
Sacrificing Soldiers on the National Mall
}

\author{
Kristin Ann Hass
}

\section{따}

U N I VERSITY OF CALIFOR N A PRESS

BERKELEY LOS ANGELES LONDON 
Parts of chapter I were published in a different form as "Remembering the 'Forgotten War' and Containing the 'Remembered War': Insistent Nationalism and the Transnational Memory of the Korean War," in Transnational American Memories, ed. Udo J. Hebel (Berlin: Walter de Gruyter, 2009). Parts of chapter 2 were published previously as a book review, "Peggy Pascoe's What Comes Naturally: Miscegenation Law and the Making of Race in America and the Use of Legal History to Police Social Boundaries," Michigan State Law Review 2011, no. I (2011): 255-6I.

University of California Press, one of the most distinguished university presses in the United States, enriches lives around the world by advancing scholarship in the humanities, social sciences, and natural sciences. Its activities are supported by the UC Press Foundation and by philanthropic contributions from individuals and institutions. For more information, visit www.ucpress.edu.

University of California Press

Berkeley and Los Angeles, California

University of California Press, Ltd.

London, England

(C) 2013 by The Regents of the University of California

Library of Congress Cataloging-in-Publication Data

Hass, Kristin Ann, 1965-.

Sacrificing soldiers on the National Mall / Kristin Ann Hass. p. cm.

Includes bibliographical references and index.

ISBN 978-0-520-27410-5 (cloth : alk. paper)

ISBN 978-0-520-2741I-2 (pbk. : alk. paper)

ISBN 978-0-520-95475-5 (ebook)

I. Mall, The (Washington, D.C.). 2. War memorials-Washington

(D.C.). 3. World War II Memorial (Washington, D.C.). 4. Korean War Veterans Memorial (Washington, D.C.). 5. National Japanese American Memorial to Patriotism (Washington, D.C.). 6. Memorialization-United States. 7. Collective memory-United States. I. Title.

$$
\begin{aligned}
& \mathrm{F}_{2} \text { O3.5. } \mathrm{M}_{2} \mathrm{H}_{377} \quad 2013 \\
& \text { 975.3- } \mathrm{dc}_{23}
\end{aligned}
$$

2012044182

Manufactured in the United States of America

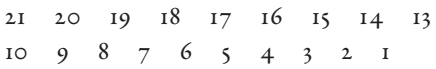

In keeping with a commitment to support environmentally responsible and sustainable printing practices, UC Press has printed this book on Rolland Enviroroo, a I00\% postconsumer fiber paper that is FSC certified, deinked, processed chlorine-free, and manufactured with renewable biogas energy. It is acid-free and EcoLogo certified. 
For Cameron, Finn, Cole, and Hazel 
